\title{
COMMENTS
}

\section{JURISDICTIONAL CONFLICTS UNDER THE NATURAL GAS ACT}

While Congress has power to provide for control of local commerce in order to "foster and protect interstate commerce," it chose by the Natural Gas Act ${ }^{2}$ merely to "fill the gap in regulation that ... exist[ed] by reason of the lack of authority of the state commissions." 3 Consequently, Section I(b) of the Act provided that the Federal Power Commission should have no jurisdiction over direct sales to ultimate consumers, or over the "local distribution of natural gas ... or ... the production and gathering of natural gas," 4 areas in which local action was unrestricted. 5 The Commission's jurisdiction was thereby limited to control over the interstate transportation and sale for resale of natural gas, a middle zone bounded by production and gathering at one end and by local distribution at the other. Recent cases, ${ }^{6}$ proposed legislation, ${ }^{7}$ and testimony before the Commission during the recent Natural Gas Investigation ${ }^{8}$ have emphasized some difficulties of regulation which result from this delimitation of the Commission's hegemony. At a time when the Commission is being criticized for unduly encroaching on local regulation, 9 it seems appropriate to consider some

I See Houston, East \& West Texas Ry. Co. v. United States, 234 U.S. 342, 353 (1913).



3 H.R. Rep. 709, 75th Cong. rst Sess., at 3 (I937).

$45_{2}$ Stat. 821 (1938), 15 U.S.C.A. $\$ 717$ (I948).

5 Pennsylvania Gas Co. v. Pub. Service Comm'n, 252 U.S. 23, 3I (rg2o) (state commissions can regulate interstate sales made direct to ultimate consumers since the "service rendered is essentially local"); Pub. Utilities Comm'n v. Landon, 249 U.S. 236,245 (I919) (it can not be said that "sale and delivery of gas to their customers at burner-tips by the local companies ... constituted any part of interstate commerce"); Champlin Refining Co. v. Corp. Comm'n, 286 U.S. 2ro, 235 (1932) (petroleum production "is not a part of interstate commerce even though the product is intended to be and in fact is immediately shipped in such commerce").

'Federal Power Comm'n v. Panhandle Eastern Pipeline Co., 337 U.S. 498 (I949); Federa ${ }^{1}$ Power Comm'n v. East Ohio Gas Co., 338 U.S. 464 (I950).

7 H.R. 1758 and S. 1498 , 8 rst Cong. Ist Sess., bills to insure the immunity of natural gas producers and gatherers from federal regulation; and H.R. $400 \mathrm{I}$, H.R. 4028 , and S. I83I, 81 Ist Cong. Ist Sess., bills to exempt certain local retail and wholesale distributors from federal control.

8 This investigation, instituted in Docket No. G-580, 4 F.P.C. 725 (1944), was reported in two separate documents because of differing interpretations of the voluminous testimony presented. Commissioners Smith and Wimberly comprised one faction, and Commissioners Draper and Olds the other.

9 See, for example, the statement by Representative Lyle that the Commission has assumed "full control over the production and gathering of natural gas directly contrary to the express provisions of the ... Act," in Hearings before a Subcommittee of the House Committee on 
of these problems which result from the complementary character of the Natural Gas Act. The status of regulation in three areas will be considered: (I) regulation of the price of natural gas at the completion of production and gathering, ${ }^{10}$ but before it has started to move in interstate commerce; (2) control of local rates; and (3) authority to direct natural gas into the most socially desirable uses, the problem of end use.

\section{I}

State regulation of production and gathering prior to the Act was limited to measures encouraging conservation and equitable sharing of output among well owners. ${ }^{\mathrm{II}}$ Since local regulation of price at the well head was not practiced, ${ }^{\mathrm{Ix}}$ it is not obvious that such regulation was meant to be shielded by the production and gathering exception. The question whether regulation of sales of gas to interstate pipeline companies was to be deemed an exclusively local prerogative was decided by the Commission in In re Columbian Fuel Corporation. ${ }^{13}$ On the basis of the legislative history of the Act the Commission declined jurisdiction. In reaching this result the Commission reasoned that if the producing company was under regulation as to one incident of production and gathering, sales in the field, jurisdiction could be extended to other aspects more clearly intended by Congress to remain subject only to state control. The Commission did not surrender its power to review rates charged between affliates, and it recognized that the question might have to be reconsidered if experience revealed that producing and gathering companies were "able to maintain an unreasonable price despite the appearance of competition." ${ }_{14}$

Two subsequent cases limited but by no means emasculated the Columbian

Interstate and Foreign Commerce on H.R. 79, H.R. 1758, and H.R. 982, 8Ist Cong. Ist Sess., at I7 (I949); and see Lippitt, Is the FPC Encroaching on Local Gas Regulation?, 45 Pub.

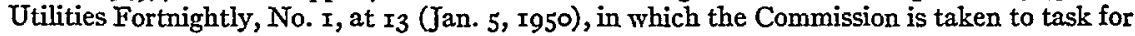
asserting jurisdiction over the local distribution.

so Production and gathering includes the operations by which gas is withdrawn from the earth, processed, and brought by feeding lines from the field to central points of connection with transmission systems; see FPC, Natural Gas Investigation (Smith-Wimberly Report) IO8 (I948).

Ir Leading oil and gas producing states enacted comprehensive conservation laws in the two decades from I9I5-35: Okla. L. (I915) c. I97; La. Acts (r9r8) acts 268 and 270; Ark. Acts (1923) act 664; N.M.L. (I925) c. I2r; Mich. Pub. Acts (1929) act I5; Cal. Stat. (I929) c. 535; Miss. Gen. L. (r932) c. rr 7 ; and Tex. L. (r935) c. r20. Frequently included in these acts were: standards as to the drilling, producing, casing, capping, abandonment, and plugging of wells; well-spacing regulations; limitations on withdrawals (proration) from common pools; requirements that purchasers of gas take ratably from all producers in a given field or pool. For a survey of state conservation laws and activities, see FPC, op. cit. supra note ro, at I2I-54.

12 A tabulation of provisions in state conservation laws shows no state commission having express authority to fix well head prices. Ibid., facing 128 . Despite the lack of statutory authority, the Kansas State Corp. Comm'n has recently held that it had the power to impose an $\$ 0.08$ minimum price for gas sold in the Hugoton field. In re Hugoton Gas Field, 77 P.U.R. (N.S.) 150 (I949).

132 F.P.C. 200 (1940).

$\mathbf{r}_{4}$ Tbid., at 208. 
rule. In the Billings case, ${ }^{15}$ the Commission held that sales for resale by a gas company which transported gas received at termini at the state line were sales in interstate commerce subject to regulation under the Act. That company was not a producer or gatherer, but one of several transporters of gas whose interconnected facilities promoted a continuous flow of gas in interstate commerce. In the Interstate case, ${ }^{16}$ sales by an interstate pipeline company of gas produced by it to another interstate transmitting company were held to be within the Commission's jurisdiction, although made within the home state of the seller. The rationale was that the sales were initiated after the gas had started on its interstate journey and not at the completion of production and gathering. In upholding the Commission's ruling ${ }_{2}{ }^{x 7}$ the Supreme Court was influenced by the circumstance that petitioner had earlier stressed the interstate character of its business in evading regulation by the Louisiana Public Service Commission. The Court said: "In denying the Federal Power Commission jurisdiction to regulate the production or gathering of natural gas, it was not the purpose of Congress to free companies . . . from effective public control." 18

The facts of the Interstate case seem plainly distinguishable from those of In re Columbian Fuel Corporation in which the Commission had announced the immunity of sales made prior to the commencement of interstate transport of the gas. Nevertheless, it is claimed that because of the Interstate decision independent producers fear federal regulation and are withholding natural gas from interstate commerce. ${ }^{\mathrm{x}}$. That there has been no repudiation of the Columbian doctrine is indicated by a reaffirmation of ${ }^{2} t^{20}$ and by a Commission order assuring "independent producers and gatherers . . . that they can sell at arm's length ... without apprehension ... [of] assertions of jurisdiction by the Commission. ..." ${ }^{2 x}$ Some members of the Commission are not in sympathy with the $\mathrm{Co}$ lumbian rule; ;2 $^{22}$ no intention to assume jurisdiction over such sales can prop-

is In re Billings Gas Co., 2 F.P.C. 288 (I940).

${ }^{26}$ In re Interstate Natural Gas Co., 3 F.P.C. 416 (I943).

${ }_{17}$ Interstate Natural Gas Co. v. Federal Power Comm'n, 33 I U.S. 682 (I947).

28 Ibid., at 690 .

19 An industry representative asserted that producers would boycott the interstate pipelines and sell to other purchasers, "not because of any technical need but to avoid sales under arduous circumstances." Quoted in FPC, op. cit. supra note Io, at 170 .

${ }^{20}$ In re Fin-Ker Oil \& Gas Prod. Co., 6 F.P.C. 92 (I947) (no jurisdiction because "[i]ts natural gas operations are confined to production and gathering and the sale upon completion of gatherings of such produced gas").

21 FPC Order No. I39 (I947), printed in Hearings, op. cit. supra note 9, at go.

22 Former Commissioner John W. Scott wrote a strong dissent in the Columbian case, and former Commissioner Olds recently expressed regret over not having joined in dissenting, in Hearings, op. cit. supra note 9, 2I4; Commissioner Draper dissented to Order No. I39 and recently was joined by Commissioner Buchanan in a letter to Representative Harris advocating its rescission, in 95 Cong. Rec. II000 (July I8, I949); Mr. Olds also changed his position with respect to Order No. r39, see Hearings, op. cit. supra note 2 I, at 225 . 
erly be inferred from the opposition of a majority of the Commission to proposed amendments directed at clarification of the scope of federal control in this area. The bills are considered objectionable because it is thought that they might preclude regulation of sales not at arm's length ${ }^{23}$ or would permit transactions inimical to another phase of federal rate regulation. ${ }^{24}$ It is evident, therefore, that the Columbian rule is intact, so that gas produced by independent producers and sold to nonaffliated interstate pipeline companies remains free of federal regulation.

No distinction is to be found in the words of the Act between gas which is produced by independent producers and that produced by interstate pipeline companies. However, Supreme Court decisions giving wide administrative discretion in computing utility rate bases have made it possible for the Commission to apply utility principles in determining the value of gas produced and carried by such integrated companies.s

Congress, in the Natural Gas Act, specified that all rates charged by a natural gas company "for or in connection with the transportation or sale of natural gas ..." should be "just and reasonable." In the Hope case, the Supreme Court said: "If the total effect of the rate order cannot be said to be unjust and unreasonable, judicial inquiry under the Act is at an end." ${ }^{\prime 27}$ A rate is just and reasonable as far as the investor is concerned, when the return to him is commensurate with returns on other investments involving similar risks and when it is sufficient to insure satisfactory operation and to maintain confidence in the financial integrity of the enterprise. Under the Hope doctrine, so long as these standards of reasonableness were fulfilled, the Commission was not obligated to consider estimates of reproduction or replacement cost, but could use original cost valuations in compiling a rate base.

Whether the Commission was free under these standards to include produc-

${ }^{23}$ Hearings, op. cit. supra note 9, Appendix I to Majority Report of the Federal Power Commission on H.R. 79 and H.R. I758, 8rst Cong. Ist Sess., at 176 (I949).

24 It was feared that under the proposed law "a natural gas company could create a situation which would require the Commission, in fixing rates, to allow as an operating expense the market value of gas" produced by that company. This, it was thought, could be done under the proposed amendment by "the expedient of creating a new corporation to own and operate the pipeline company's production and gathering properties." Tbid., at 175 .

25 For a brief history of valuation standards, see Troxel, Economics of Public Utilities 285308 (I947). The recent trend has been away from adherence to a formula of fair return on fair value in which the base was compounded from original cost and reproduction cost valuations; see Smyth v. Ames, 169 U.S. 466 ( 1898 ); and see Bonbright, Contributions of the Federal Power Commission to the Establishment of the Prudent Investment Doctrine of Rate Making, ${ }_{44}$ Geo. Wash. L. Rev. ${ }_{3} 6$ (I945), in which the author writes, "[J]udged by its influence on utility regulation ... the most important accomplishment of the Federal Power Commission has been its successful effort to establish a 'prudent investment' principle of rate control and to defend [it] . . . against attack based partly on the assumed constitutional requirement of a 'reasonable return on fair value." "

${ }^{36} 5^{2}$ Stat. 822 (I939), 55 U.S.C.A. \& 7 I7 (c)(a) (I948).

${ }^{37}$ Federal Power Comm'n v. Hope Natural Gas Co., 320 U.S. 59I, 602 (x944). 
tion and gathering facilities in a rate base at original cost depended on decisions both as to the reasonableness of a rate order so determined and as to the authority of the Commission, in the light of Section I(b) of the Act, to consider those portions of the company's total investment. In the Canadian River case, the Supreme Court in a five-to-four decision affirmed the validity if not the wisdom of such a rate base. ${ }^{28}$ The contention that "contrary to the mandate of Section I (b) the Commission has undertaken to regulate the production and gathering of natural gas" was dismissed by the Court, since the Commission had not "imposed any direct regulation upon that activity." ${ }_{29}$ In addition, since the resulting rates were fair, the Hope decision prevented any further inquiry into the methods by which they were made.

Since pipeline companies and their affiliates provided in the neighborhood of forty per cent of the gas supply of interstate companies reporting to the Commission in $1947,3^{\circ}$ the indirect control of production and gathering authorized in the Canadian River case has had an appreciable effect on subsequent natural gas rate regulation. Under the method presently employed in setting rates for an integrated production and transportation company, such a company is treated as a single unit, with no distinction being made between the two aspects of its operations. An aggregate rate base is computed including original investment in both branches of the business, and the company's net earnings are limited to a fixed percentage of that base. Costs of gas production, including all expenses incidental to development of gas properties are recognized as legitimate operating costs. ${ }^{3^{\mathrm{x}}}$ Since the sum of cost of production plus a percentage of the original cost of the producing facilities is considerably less than the going well head price received by independent producers, ${ }^{32}$ the industry has agitated for the adoption of a "field price formula" which would do away with the alleged discrimination. Under that method, production properties would be excluded from the rate base, no allowance would be given for expenses incurred in producing gas, and produced gas would be treated exactly as if it had been purchased from independent producers at prevailing field prices. While the valuation base for the enterprise would be somewhat reduced, an "operating expense" substantially in excess of

${ }^{28}$ Canadian River Natural Gas Co. v. Federal Power Comm'n, 324 U.S. 58x (rg45). Justice Jackson, who concurred only because the Hope case made it impossible for him to do otherwise, described the method used by the Commission as "fantastic." Ibid., at 6II.

29 Ibid., at 609 .

${ }^{30}$ Hearings, op. cit. supra note 9 , Table 7 , at $18 \mathrm{I}$.

${ }^{3 x}$ For records of Commission rate proceedings carried out in accord with these principles, see In re Canadian River Gas Co., 3 F.P.C. 32 (1942); Detroit v. Panhandle Eastern Pipeline Co., 3 F.P.C. 273 (1942); In re Alleghany Gas Co., 5 F.P.C. I (1946); Columbus v. United Fuel Gas Co., 5 F.P.C. 279 (1946).

${ }^{32}$ Basing their computations on field prices specified in existing contracts, Commissioners Smith and Wimberly found differentials between cost of production and field price to be: $\$ 0.0067$ per Mcf. for Panhandle Eastern, \$0.0245 per Mcf. for Colorado Interstate, \$0.03II per Mcf. for Cities Service Gas Co., \$0.0289 per Mcf. for Natural Gas Pipeline Co. FPC, op. cit. supra note ro, at 228 . 
actual cost of production would be available as a revenue reduction before computation of the company's net income.

Two members of the Commission favor modification of present policy along these lines, ${ }^{33}$ and one section of the Rizley bill, which was before Congress in I947, would have compelled the Commission to use the field-price method. ${ }^{34} \mathrm{An}$ industry rate expert recently expressed the opinion that unless "fair field price legislation is . . . enacted . . . there will be a marked trend away from the dedication by the pipeline companies of producing properties to the interstate transportation of gas. This trend will manifest itself . . . by the distribution or sale of producing properties by their pipeline owners." 35 That sentiment was echoed by an official of Panhandle Eastern Pipeline Company, an integrated company of the kind under discussion, who declared his readiness to "begin steps to circumvent this type of discrimination." ${ }^{6}$

That apparently was no idle threat, for in September, I948, Panhandle organized the Hugoton Production Company, and in return for all its capital stock transferred to it gas leases on approximately 97,000 acres of land in Kansas and $\$ 675,000$ in cash. The Hugoton stock was ultimately distributed to the stockholders of Panhandle. An investigation of the entire transaction was ordered by the Commission, and the two companies directed to show cause why Panhandle should not be prohibited from transferring the leases without the consent of the Commission. When the companies ignored an order to maintain the status quo pending a final determination, the Commission sought injunctive relief. This was denied by the district court and by the circuit court of appeals, ${ }^{37}$ and the Supreme Court upheld their rulings, in Federal Power Commission v. Panhandle Eastern Pipaline Co.38

The Supreme Court decision is based on the premise that "leases are an essential part of production" and, as such, their acquisition and sale is a matter precluded from federal control by the limitations of Section I(b). ${ }^{39}$ Section I4(b) which confers power to "determine the adequacy or inadequacy of gas re-

${ }^{33}$ Commissioners Smith and Wimberly concluded from the findings of the Natural Gas Investigation that "a standard of fair field price or reasonable value, which will make appropriate allowance in each instance for the value of such gas as a commodity, should . . . be adopted and applied. ..." FPC, op. cit. supra note Io, at 234 .

34 Section $5 \frac{1}{2}$ provided: "The Commission ... shall allow to a natural gas company as an operating expense ... if the gas is produced by such natural gas company ... the prevailing market price in the field ... or if there is no prevailing market price ... the fair and reasonable value of such gas...." The bill is printed in Hearings before a Subcommittee of the Senate Committee on Interstate and Foreign Commerce on H.R. 405x, 8oth Cong. 2d Sess., at 35 (r947).

35 Tbid., at 22.

${ }^{36}$ Statement of $\mathrm{E}$. Buddrus during the Natural Gas Investigation quoted in FPC, op. cit. supra note ro, at $212 \mathrm{n}$.

37 Federal Power Comm'n v. Panhandle Eastern Pipeline Co., I72 F. 2d 57 (1949).

${ }^{38} 337$ U.S. 498 (I949).

39 Ibid., at 505 . 
serves," $4^{\circ}$ was construed as giving "only power to obtain information," although as Justice Black observes in a vigorous dissenting opinion, that interpretation "leaves the Commission impotent to protect the public's interest in having interstate companies maintain adequate gas reserves." ${ }^{1}$ The latter opinion makes sense, for if findings of inadequacy are to have any meaning there must be power to restrain acts which would jeopardize the sufficiency of reserves. The dissent is also supported by the dictum in the Canadian River case which implies that the production and gathering exception relates only to physical operations, such as "the drilling and spacing of wells. ..." ${ }^{2}$ On the other hand, since before the Act local authorities might have regulated such transactions in order to protect some local interest, 43 the majority's view is not inconsistent with the expressed intent of Congress to effect federal regulation only in those spheres in which the states could not act.

While the dissenting opinion referred primarily to the unfortunate gap the decision creates in service regulation, the Commission was quick to announce that substantial rate increases might be expected to result. 44 The way in which the divorcement operates as a means of circumventing the effects of original cost valuation of producing facilities is clear. Hugoton, the new production company, will (after 1965 ) 45 sell gas to Panhandle to be sent through interstate pipelines and sold to local distributors. Panhandle will claim as an expense of its operation the price paid for that gas. Consequently the Commission will be compelled to allow Panhandle to charge rates sufficient to produce revenue covering the added operating expense in addition to the customary percentage of the depreciated original cost of the property retained in the regulated business. Panhandle's net earnings will be reduced by six per cent of the original cost of the property conveyed; but the return from producing facilities will be greater by the difference between the field price and cost of production including the

$$
{ }^{40} 5^{2} \text { Stat. } 828 \text { (I938), I5 U.S.C.A. } \$ 7_{77} \text { (m)(b) (I948). }
$$

47 Federal Power Comm'n v. Panhandle Eastern Pipeline Co., 337 U.S. 498, 518 (1949). Justice Black suggests near the close of his dissenting opinion that the transfers could result in rate increases, indicating that while he wrote chiefly about the necessity of maintaining "adequate gas reserves" he was not unaware that issues of rate policy were involved as well.

$4_{2}$ Canadian River Natural Gas Co. v. Federal Power Comm'n, 324 U.S. 58x, 603 (I945); and see Interstate Natural Gas Co. v. Federal Power comm'n, 33I U.S. 682, 690 (I947).

${ }^{43}$ Although such authority is not expressed in conservation statutes, liberal construction of these statutes in the interest of gas conservation is the usual course; cf. In re Hugoton Gas Field, 77 P.U.R. (N.S.) I50 (I949).

it A spokesman for the Commission was reported to have said that the ruling in favor of Panhandle provided a loophole for natural gas companies to get increased revenues and it was estimated that rates of eleven companies would be increased by about $\$ 56, \infty 0,000$ a year. WallSt. J., § I, p. 8, col. 2 (June 2r, I949). This estimate is clearly exaggerated, see p. 486 infra.

45 Hugoton after getting the gas reserves contracted to sell the gas produced from them to the Kansas Power and Light Co. for a period of fifteen years, after which time Panhandle was to have the option to purchase all or part of the gas produced. 
usual rate of return on original investment. ${ }^{6}$ That difference, representing the producing company's profit in excess of the return allowed Panhandle, will be distributed to Hugoton's stockholders who also are the owners of Panhandle.47 Making appropriate assumptions as to gas yield per acre, costs, including return on investment, and field price, the potential added revenue over the life of the leases would be approximately $\$ 34,000,000.4^{8}$ If the nine major pipelines owning gas reserves were to dispose of them in this way as they are now free to do, annual rate increases of nearly $\$ 25,000,000$ would be possible. 49 The magnitude of the increase is seen when it is realized that annual rate reductions secured by the Commission amount to less than $\$ 40,000,000 . .^{50}$

While the issue of cost to consumers has consistently been raised when proposals to alter rate policy are put forth, s $^{\mathrm{x}}$ the "public interest is a texture of multiple strands" ${ }^{2}$ and it is possible that regulation of producing facilities on an original cost basis is inadvisable. Exploration, conservation, and the entry of new capital may be deterred under prevailing Commission practice. Arguments to this effect were presented by the industry during the Natural Gas Investigation, ${ }^{53}$ and were instrumental in bringing Commissioners Smith and Wimberly to advocate adoption of the field price method.54 Divorcement of production and gathering facilities, however, accomplishes more than merely securing a replacement cost or field-price method of rate regulation. Such separation, in conjunction with the Columbian rule, will enable an increased amount of gas to enter

${ }^{46}$ The Commission's Bureau of Accounts, Finance, and Rates assumed a six per cent rate of return in its analysis of the effects of the Rizley bill on Panhandle. Hearings, op. cit. supra note 34 , at 3 II.

47 Following the Supreme Court's decision in the Panhandle case, stockholders of that company were mailed stock certificates representing 810,000 capital shares in Hugoton. Wall St. J., § I, p. ro, col. 8 (June 24, I949).

$4^{8}$ The Bureau of Accounts, Finance, and Rates in analyzing the effects on Panhandle of adopting the field price method assumed a cost of production of \$0.035 per Micf., including return at six per cent and a field price of \$0.07 per Mcf. Hearings, op. cit. supra note 34 , at 3 ro-r2. In these computations, however, a field price of \$0.08 per Mcf. has been used because of the action taken by the Kansas Corp. Comm'n in fixing an \$o.08 minimum in the Hugoton field. Gas yield per acre is typically estimated at 7,500 MMcf. See, for example, FPC, The Natural Gas Investigation (Olds-Draper Report) 147 (I948).

49 Hearings, op. cit. supra note $2 \mathrm{I}$, Table $2 \mathrm{I}$, at $\mathrm{I} 88$.

so Hearings, op. cit. supra note 9 , Table 18 , at 187 .

${ }^{5}$ See, for example, speech by Representative Yates in debates on the Harris bill, 95 Cong. Rec. I0992 (Aug. 4, I949); and, also, testimony by the City Solicitor of Pittsburgh, Pa. as to the savings brought to residents of that city, in Hearings, op. cit. supra note 34 , at 35 .

sa Justice Frankfurter, dissenting in Federal Power Comm'n v. Hope Natural Gas Co., 320 U.S. 59r, 627 (r944).

53 See FPC, op. cit. supra note ro, at $177-223$; Commissioners Draper and Olds regarded these arguments as mere camouflage for the "real price objective" which was a price "based on 'all that the traffic' in the competitive fuel market 'will bear'." FPC, op. cit. supra note 48 , at $136-37$.

54 See note 33 supra. 
interstate commerce subject to no federal regulation whatsoever. Since commissions in producing states are chiefly interested in conservation and for that reason desire higher field prices, 55 no effective price limitation can be expected from that source.

This fact is significant to the extent that there is monopolization of gas reserves ${ }^{6}$ and an absence of a real conflict of interest between buyer and seller, as in the Panhandle-Hugoton situation where divorcement was accompanied by no true disaffiliation. ${ }^{57}$ It is true that the Commission can regulate sales between affiliates and that anti-trust action might be brought against monopolistic producers, but both procedures involve investigation and litigation that would be unnecessary if production and gathering of gas transported and sold in interstate commerce were subject to control as a utility. Probably there has not been sufficient deviation from competitive conditions in the field to justify repudiation of the Columbian doctrine, but where there already is control it should not be hastily abandoned..$^{8}$ By permitting such abandonment, the production and gathering exception, as applied by the Court in the Panhandle case and by the Commission in the Columbian case, has created a potential zone of nonregulation that may go far toward nullification of Commission regulation of interstate wholesale rates.

\section{II}

Unlike the production and gathering exception, the provision in Section $I(b)$ precluding Commission jurisdiction over the local distribution of natural gas was designed to leave pre-existing systems of local rate regulation unaffected by the Act. Under this division of authority, the ultimate customer is protected to the extent that local regulation is effectively performed. Typically, however, state and local commissions are afflicted with serious limitations, such as inade-

ss See FPC, op. cit. supra note 10, at I37, where Commissioners Smith and Wimberly remark: "During the course of the investigation it was strongly and repeatedly urged in the producing states that higher field prices for gas, making it worth saving, would be the greatest single boon to its effective conservation."

${ }^{56}$ In I947 nearly one-half of the sales of natural gas to pipelines operating out of seven Southwestern states were made by ten independent producers, while over fifty per cent of the total gas acreage in the United States was owned or controlled by fourteen top companies. Hearings, op. cit. supra note $2 \mathrm{r}$, at $I 7$. Commissioners Smith and Wimberly found no evidence of monopoly "with respect to gas reserves as a whole, although in particular areas or fields certain companies may be dominant." They then remark that ownership by strong interests may "help to stabilize prices..." due to their ability "to hold reserves for future markets..." ; FPC, op. cit. supra note ro, at 63 .

57 In the discussion of the divorcement possibility in the Smith-Wimberly Report on the Natural Gas Investigation it was suggested that a divestiture created by merely distributing the ownership among stockholders "would present questions as to whether a true separation had actually been accomplished." FPC, op. cit. supra note Io, at $213 \mathrm{n}$.

${ }^{8}$ Faced with a similar situation when the Rizley bill was under consideration, the Senate subcommittee concluded in its unfavorable report, "[I]n the face of the growing concentration of control of reserves, regulatory safeguards should not be abandoned . . . , but rather they should be strengthened." Hearings, op. cit. supra note 35 , at 580 . 
quate statutory scope, ${ }^{59}$ underfinancing, ${ }^{60}$ and political and utility influence in the appointment of commissioners. ${ }^{65}$ The Commission, therefore, has attempted to push forward its jurisdiction to include some companies engaged in selling natural gas locally. Recently, in Federal Power Commission v. East Ohio Gas Company, ${ }^{62}$ the Supreme Court upheld the validity of such an extension.

East Ohio operates a natural gas business wholly in Ohio, selling gas to retail customers through a number of local distribution systems. It gets its gas supply from two interstate pipeline companies, its high pressure line receiving the imported gas inside the Ohio boundary. The Commission's contention that East Ohio's transport of this gas to the points of local distribution constituted interstate transportation of natural gas, making it a natural gas company under the Act, was upheld by the Court. Although Supreme Court decisions subsequent to the Act imply that state regulation of intrastate high pressure facilities is permissible, $6_{3}$ the majority held that to be irrelevant since "prior constitutional decisions ... form the measure of the gap which Congress intended to close. ..."64 Final authority over sales to ultimate consumers continues to be vested in state commissions, but so long as a retail company persists in transporting gas produced outside of the state at high pressure ${ }^{65}$ it can be required ( $I$ ) to provide

59 See Trachsel, Public Utility Regulation ${ }^{52}$ (I947), where the author remarks, "Although commission jurisdiction is being gradually extended, it is still far from adequate in the great majority of states and may be listed as one of the chief defects in state commission regulation."

${ }^{60}$ In I934-35 the total expenditure for all the state utility commissions was approximately $\$ 9,563,000$, and nearly one-half of that sum was spent by New York, Pennsylvania, Wisconsin, Illinois, and Missouri. Mosher and Bonbright, Public Regulation of Private Electric and Gas Utilities, Third World Power Conference, Sec. III, Paper No. 8, at 8-9 (r936). The results of underfinancing, such as inadequate stafing, neglect of statutory responsibilities, and lack of independent study of long range problems are discussed in Mosher and Crawford, Public Utility Regulation $67-8 x$ ( 1933 ).

6r See Bauer and Gold, Electric Power Industry 243-45 (x939); Mosher and Crawford, op. cit. supra note 60 , at 56-57; and also, Troxel, op. cit. supra note 25 , at $79-83$.

${ }^{6} 338$ U.S. 464 (1950).

${ }^{6} 3$ See Panhandle Eastern Pipeline Co. v. Pub. Service Comm'n of Ind., 332 U.S. 507, 5I2 (I947), where the Court, speaking of pressure reduction as a criterion of local or federal control, says, "[t] $]$ hose merely mechanical considerations are no longer effective, if ever they were exclusively, to determine for regulatory purposes the interstate or intrastate character of the continuous movement and resulting sales..."; cf. Interstate Natural Gas Co. v. Federal Power Comm'n, 33x U.S. 682, 689 (1947), where the Court was unimpressed by the argument that interstate commerce does not begin until the gas is subjected to increased pressure at the compressor stations.

${ }^{64}$ Federal Power Comm'n v. East Ohio Gas Co., 338 U.S. 464,472 (r950). The leading case was East Ohio Gas Co. v Tax Comm'n, 283 U.S. 465 (r93I), which held the transportation of natural gas from wells outside a state by means of a distributing company's high pressure transmission lines to their connections with local systems was essentially national in character. When the gas passes into local supply mains and pressure is reduced it enters intrastate commerce.

${ }_{65}$ Forty-three companies, not selling gas for resale, but transporting gas by intrastate high pressure lines will be brought under the jurisdiction of the Commission. See Lippitt, op. cit. supra note 9 , at $x 8$. 
the Commission with information as to original cost of all or any part of its property, ${ }^{60}(2)$ to keep accounts and records as the Commission may direct, ${ }^{67}(3)$ to submit to investigations to determine the cost of transportation of natural gas, ${ }^{68}$ and (4) to secure certificates of convenience and necessity from the Commission when any abandonment of its high pressure facilities is contemplated. ${ }^{69}$ Federal control in the last matter precludes state regulation, but the Act expressly provides that there may be duplicate bookkeeping. ${ }^{70}$ The situation created is one in which East Ohio must either keep its books contrary to the orders of the Ohio commission or else keep two sets of records. The probable result is that the Ohio commission will change from reproduction cost to original cost standards of valuation, and otherwise modify its accounting procedures to conform with federal practice. Justice Jackson suggests in his dissenting opinion that in situations such as this "experience shows state control will wither away and leave the federal rule in possession of the field." $7 \mathrm{I}$ If this prognosis proves correct, local rate reductions in some states should follow, compensating, in part, for the rate increases to be expected as more integrated companies take advantage of the course opened to them by the Panhandle decision.

\section{III}

The cleanliness and ease of control of natural gas make it especially suitable for space heating, cooking, refrigeration, and other domestic uses; but there are any number of other more or less inferior ways in which natural gas may be utilized. ${ }^{72}$ Utility regulation, which serves as a substitute for regulation by the competitive market, must aim at the optimum allocation of resources. Thus a primary objective of natural gas regulation must be to minimize inferior use, which is tantamount to waste. ${ }^{73}$ The divided regulatory authority which exists

${ }^{66} 5_{2}$ Stat. 824 ( $\left.{ }_{938} 8\right)$, ${ }_{5}$ U.S.C.A. $\& 77_{7}(\mathrm{e})(\mathrm{b})$ (I948).

${ }^{67} 5^{2}$ Stat. 825 (1938), ${ }_{5}$ U.S.C.A. $\$ 717$ (g)(a) (1948).

${ }^{68} 5_{2}$ Stat. 825 ( $\left.\mathrm{I}_{938}\right)$, $\mathrm{r}_{5}$ U.S.C.A. $\& 7 \mathrm{rr}_{7}(\mathrm{~g})$ (b) (1948).

${ }^{69} 52$ Stat. 824 (r938), as amended, ${ }_{5}$ U.S.C.A. $\$ 7 r_{7}(f)$ (r948).

${ }^{70} 5_{2}$ Stat. 825 (1938), ${ }_{5}$ U.S.C.A. $87 \mathrm{r} 7 \mathrm{~g}$ (a) (I948), provides: "[N]othing in this chapter shall relieve any such natural gas company from keeping any accounts, memoranda, or records which such natural gas company may be required to keep by or under authority of the laws of any state."

7 Federal Power Comm'n v. East Ohio Gas Co., 338 U.S. 464, 478 (I950); and see Lippitt, op. cit. supra note 9, at 20 , where the author predicts a possible "decline in importance of state public utility regulation and an ascendance of Federal regulatory activities...." Legislation has been introduced to secure complete exemption of companies selling and delivering natural gas directly to ultimate consumers within a particular state. See note 7 supra.

iz See Blachly and Oatman, Natural Gas and the Public Interest I6-r8 (I947), for enumeration including inter alia use as an industrial fuel, as a force for driving oil through porous sands, as a raw material in the manufacture of carbon black, motor and aviation fuels, and countless other products.

${ }^{73}$ Conservation is, of course, an important aspect of this problem. Action by the states, individually and through the Interstate Oil Compact Commission, has been reasonably effec- 
under the Natural Gas Act not only limits the comprehensiveness of rate regulation in the ways already discussed, but fails to effect an optimum allocation of the available supply of natural gas between competing uses and regions. Some states have imposed restrictions on the use to which gas may be put within the state, ${ }^{74}$ but state control of gas use outside the state is of questionable constitutional validity. ${ }^{75}$ Despite the inability of the states to act in this regard, the Act as originally passed gave the Commission no express authority over the ultimate disposition of gas carried in interstate commerce. This defect was partially remedied by an amendment to the certificate provisions of the Act which provided that the Commission "shall have the power to attach to the issuance of the certificate and to the exercise of the rights granted thereunder such reasonable terms and conditions as the public convenience and necessity may require." ${ }_{76}$ Under this provision, the Commission has issued a certificate modified by the condition that gas transported by the new facilities not be used as a boiler fuel, 77 and has provided in another that the facilities authorized should "not be used for the transportation or sale of natural gas to any new customers... except upon specific authorization. ..." "78 The Commission also has asserted its right to issue certificates authorizing the construction of facilities for delivering gas to industrial customers purchasing from interstate pipeline companies rather than from local gas distributors. ${ }^{79}$ With respect to such direct industrial sales made through established pipelines the Commission has no control, except when such sales would render the interstate pipeline unable to meet its commitments under schedules filed with the Commission. ${ }^{80}$ Lack of authority to fix rates for

tive in halting waste in the field. For example, testimony during the Natural Gas Investigation indicated that flaring has disappeared in dry gas fields and only remains a problem where gas is found in association with oil. FPC, op. cit. supra note 9, at II5-I6; and see Blachly and Oatman, op. cit. supra note 72 , at 67 .

74 See Blachly and Oatman, op. cit. supra note 72 at 66 . Use in the manufacture of carbon black is most frequently proscribed.

${ }^{75}$ See Haskell v. Kansas Natural Gas Co., 224 U.S. 217, 220 (xgI2), where the Court says, "[N]atural gas after severance is a commodity . . . like ... coal and other minerals, and is a legitimate subject of interstate commerce; and ... no State . . can prohibit its transportation in interstate commerce beyond the lines of that State."

${ }^{76} 5^{6}$ Stat. 83 (1942).

77 Northern Natural Gas Co., 4 F.P.C. Iog9 (I945).

${ }^{78}$ In re Memphis Natural Gas Co., 4 F.P.C. 197 (1944).

79 Panhandle Eastern Pipeline Co. v Pub. Service Comm'n of Ind., 332 U.S. 507 (I947) affirmed the exclusive jurisdiction of the states over direct industrial sales. The states have not always exercised this power. Ill. Commexce Comm'n v. Mississippi River Fuel Corp., 77 P.U.R. (N.S.) I2 (I949).

80 The Commission can prohibit direct sales of gas to be delivered by means of regulated facilities "where ... a company has not the capacity to sell a large quantity to a new customer without impairing its ability to render satisfactory service to existing customers. ..." Detroit v. Panhandle Eastern Pipeline Co., 5 F.P.C. 43, 50 (I946). 
direct industrial sales leaves the Commission impotent to establish minimum rates in order to bring about decreased inferior industrial use. ${ }^{8 \mathrm{r}}$

It is not to be concluded that the Federal Power Commission has been ineffectual; the vigor with which the industry has sought restricting amendment of the Act denies such an inference. Nor need it be inferred that state and local regulation has no place in a comprehensive regulatory scheme, for proper control of some aspects of conservation and local distribution may depend upon familiarity with local conditions. It is not desirable, however, that the federalstate division of authority be based upon what the Supreme Court held to be the area of constitutional state action before the interstate transportation and sale of natural gas was of major importance in the economy..$^{8 z}$ Rather, the criterion of the legitimacy of federal action in the natural gas field should be whether the proposed regulation is required to protect the national interest in securing reasonable rates and an optimum utilization of the available supply of natural gas.

\section{THE PUBLIC POLICY ASPECTS OF ADMINISTRATIVE LOBBYING CONTRACTS}

Decisions on administrative "lobbying" contracts ${ }^{x}$ well illustrate the statement that "public policy ... is a very unruly horse, and when once you get astride it you never know where it will carry you." The recent case of Moffett $v$. Arabian American Oil Co. ${ }^{3}$ furnishes an excellent opportunity to analyse the underlying theories which lead courts to deny recovery in these cases on grounds of public policy. As a background for this discussion it will be well to consider traditional views in this field.

Courts have generally agreed that improper influence "exercised over an officer of government ..." 4 does not constitute valid consideration for a con-

${ }^{8 x}$ To some extent industrial sales on an interruptible basis are required in order to maintain high capacity utilization of pipeline facilities during periods of below peak demand and thereby reduce unit costs. The importance of high load factors may be exaggerated. FPC, op. cit. supra note ro, at $25^{8-73}$.

${ }^{82}$ Extensive interstate transportation of natural gas was not feasible before "the development of high-carbon, thin-walled steel pipes ... . and the perfection of equipment for recompressing gas in transit...." U.S. Temporary Economic Committee, Monograph 36, at 8 (1940). In r921 only 149,792 MMcf. of natural gas was transported in interstate commerce; by 1945, 1,029,758 MCMcf. passed through interstate pipelines. FPC, op. cit. supra note ro, Table 2, at 247 .

Some authorities distinguish contracts to influence administrative officials and contracts to influence legislators by applying the term "lobbying" only to the latter. Annotation, 46 A.L.R. I96 (1927). The term "lobbying" has received many definitions. See 25 Words \& Phrases 463 (1940). When it is used in this note it suggests only that two parties have agreed that, for compensation, one of them will attempt to gain action desired by the other party through legislative or administrative officials. As such, no evil connotations are intended.

2 Richardson v. Mellish, 2 Bing. 229, 252 (C.P., I824).

$38_{5}$ F. Supp. 74 (N.Y., r949).

- Oscanyan v. Arms Co., 103 U.S. 26r, 273 (1880). 